Article

\title{
Length of Human Vermiform Appendix in Bangladeshi People
}

\author{
Rahman MM'1, Khalil $\mathbf{M}^{2}$, Khalil $\mathbf{M}^{3}$, Hussain $\mathbf{M}^{4}$, Rahman $\mathrm{HR}^{5}$, Mannan $\mathrm{S}^{6}$, Sultana $\mathrm{SZ}^{7}$, \\ Ahamed S
}

The study was done to find out the length of human vermiform appendix in Bangladeshi people to magnify the knowledge regarding the diverse length of human vermiform appendix in our population. A total 100 vermiform appendix were measured with different age and sex during routine postmortem examination in the autopsy laboratory of forensic medicine department of Mymensingh Medical College. This cross sectional study was done by convenient sampling technique. For convenience of differentiating the length of vermiform appendix in relation to different age and sex, findings were classified in four groups (up to 20 years, 21 to 35 years, 36 to 55 years and 56 to 70 years).

Length of vermiform appendix was $2.6 \mathrm{~cm}$ to $14 \mathrm{~cm}$. Mean length was $7.9 \mathrm{~cm}$ in female and $7.56 \mathrm{~cm}$ in male. The highest mean length of vermiform appendix in group A was $9.17 \mathrm{~cm}$ and lowest was 5.93 $\mathrm{cm}$ in group D.

Key words: Human Vermiform Appendix; Length; Bangladesh

J Bangladesh Soc Physiol. 2007 Dec;(2): 13-16 For author affiliations, see end of text.

http://www.banglajol.info/index.php/JBSP

\section{Introduction}

7 The apex of the caecal diverticulum does not grow as rapidly as the rest of it; thus the appendix is initially as small diverticulum of the caecum. The appendix increases rapidly in length, so that at birth it is relatively long tube arising from the distal end of the caecum. After birth the wall of the caecum grows unequally, with the result that the appendix come to enter its medial side. The appendix is subject to considerable variations in position. As the ascending colon elongated, the appendix may pass posterior to the caecum (retrocaecal appendix) or colon (retrocolic appendix). It may also descend over the brim of the pelvis (pelvic appendix) ${ }^{1}$

Lymphoid tissue first appeared in the human vermiform appendix about 2 weeks after birth. The number of lymphoid follicles gradually increases to a peak of about 200, between the ages of 12 and 20 years. After 30 there is an abrupt reduction to less than half and then to a

J Bangladesh Soc Physiol. 2007 Dec;(2): 13-16 trace or total absence of lymphoid tissue after 60 years. Concurrent with lymphoid atrophy was fibrosis, which partially or totally obliterates the lumen in many older persons. ${ }^{2}$ The amount of lymphoid tissue increases throughout the puberty, remains steady for the next decade, and than begins steady decreased with age. After the age of 60 virtually no lymphoid tissue remains with in the appendix and complete obliteration of the appendiceal lumen is common. ${ }^{3}$

It is thought that in the pelvic position, the blood vessels of the appendix are free from pressure, whereas in the retrocaecal and retrocolic position the vessels are compressed or kinked by the loaded caecum or the ascending colon. Pelvic variety appendix principally causes suprapubic pain from irritation of urinary bladder. Long retro-colic inflamed appendix also called subhepatic and it causes confusions with cholecystitis. 


\section{Article}

A retrocaecal appendix may cause principally right flank or back pain. Whereas preileal directs towards the spleen and if it becomes inflamed it is liable to result in general peritonitis and is the most dangerous positions.

It is thought that in the pelvic position, the blood vessels of the appendix are free from pressure, whereas in the retrocaecal and retrocolic position the vessels are compressed or kinked by the loaded caecum or the ascending colon. ${ }^{4}$

Whereas preileal directs towards the spleen and if it becomes inflamed it is liable to result in general peritonitis and is the most dangerous positions.

At birth, the appendix is found short and broad at its junction with the caecum, but differential growth of the caecum produces the typical tubular structure by about the age of 2 years. During childhood continued growth of the caecum commonly rotates the appendix in to a retrocaecal but intraperitoneal position. In approximately a quarter of cases rotation of the appendix does not occur resulting in a pelvic, sub-caecal or para-caecal position. Occasionally, the tip of the appendix becomes extraperitoneal lying behind the caecum or ascending colon. ${ }^{5}$

No relation of length of vermiform appendix and height and weight of the person. But its length gradually shrinks in old age due to replacing of lymphoid tissue by fibrous tissue ${ }^{6}$.

With this rationale in mind, present study was done to establish a Bangladeshi standard regarding length of vermiform appendix which is the basic and essential for early diagnosis to prevent complication of appendicular pathology.
Human Vermiform Appendix

\section{Methods}

In this study, one hundred normal vermiform appendix of both sex (male-60, female-40) were observed in dead bodies during routine postmortem examination due to accidental and unnatural death. Vermiform appendix of the decomposed bodies \& lacerated injured cases involving appendix or its adjacent structures were excluded from the study.

In the morgue of Mymensingh Medical College, during routine postmortem examination when the abdomen was opened by classical midline incision, the position of the vermiform appendix were observed in situ and noted in the prepared format. Then giving an incision in the right para colic gutter, caecum with appendix was excised by giving ligature. After placing the specimen in the basin, the ligature was opened \& washes out by running tape water.

Then the appendix was excised from its base. The length was measured in $\mathrm{cm}$ by a scale. In this study the cadaver ages were up to 70 years. For convenience of differentiating the changes of vermiform appendix in relation to age, collected specimens were grouped in A group (up to 20 years), B group (21 year - 35 years), C group (36 year - 55 years) $D$ \& group ( 56 yeas - 70 years). Statistical analysis was done by ANOVA.

\section{Results}

Length of vermiform appendix in $\mathrm{cm}$ in different age groups and sex are shown in Table I. Here it shows, mean length of vermiform appendix in female were 7.97, which were more than male sex, $7.56 \mathrm{~cm}$. Minimum length was $2.60 \mathrm{~cm}$ in group D. Maximum length was $14 \mathrm{~cm}$ in group $B$.

Table I: Length of vermiform appendix in different groups

\begin{tabular}{lcccccc}
\hline Age group & $\begin{array}{c}\text { Number of } \\
\text { observation } \\
\text { (n) }\end{array}$ & $\begin{array}{c}\text { Male } \\
\text { Mean } \pm \text { SE } \\
\text { length cm }\end{array}$ & $\begin{array}{c}\text { Number of } \\
\text { observation } \\
\text { (n) }\end{array}$ & $\begin{array}{c}\text { Female } \\
\text { Mean } \pm \text { SE } \\
\text { length } \mathrm{cm}\end{array}$ & $\begin{array}{c}\text { Male } \\
\text { Range } \\
\text { cm }\end{array}$ & $\begin{array}{c}\text { Female } \\
\text { Range } \\
\text { cm }\end{array}$ \\
\hline A (0 to 20 years ) & 13 & $8.25 \pm 1.84$ & 15 & $9.17 \pm 2.14$ & $6.00-11.50$ & $5.00-12.20$ \\
B (21 to 35 years) & 28 & $7.06 \pm 2.65$ & 11 & $9.00 \pm 1.83$ & $3.10-14.00$ & $6.00-12.00$ \\
C (36 to 50 years) & 10 & $7.86 \pm 2.23$ & 8 & $7.78 \pm 1.25$ & $3.50-12.00$ & $5.80-9.20$ \\
D (51 to 70 years) & 9 & $7.46 \pm 1.62$ & 6 & $5.93 \pm 3.72$ & $5.00-10.00$ & $2.60-12.40$ \\
Mean & 7.65 & & 7.97 & & \\
\hline
\end{tabular}

'n' represents the number of specimens examined in each group. The differences between groups A \& B with group C \& D is moderately significant. 
In different age group and sex the mean length of vermiform appendix in group A was maximum. In female length was more (mean $7.97 \mathrm{~cm}$ ) than male (mean $7.65 \mathrm{~cm}$ ). Range of length of vermiform appendix was $2.6 \mathrm{~cm}$ to $14 \mathrm{~cm}$.

\section{Discussion}

It was reported that the average length of the vermiform appendix in male ranged from $9.5 \mathrm{~cm}$ to and in female it being 7.8 to $11.4 \mathrm{~cm}^{7}$

In 1967, Davies and Coupland found the length of the vermiform appendix varying from 2 $20 \mathrm{~cm}$, the average being $9 \mathrm{~cm}^{8}$. In 1968 , Nyamwanza and Timms found the average length in male to be $11.44 \mathrm{~cm}$ and in female $9.57 \mathrm{~cm}$. In 1970, Sonalke reported it to vary from $2-20 \mathrm{~cm}$. In 1971, Macphail found the average length of the vermiform appendix in 220 postmortem cases to be $9.9 \mathrm{~cm}^{8}$.

In 1932, Donald and Collins studied 4680 postmortem specimens and reported that approximately $61 \%$ of its specimens were between $6-9 \mathrm{~cm}$ long. The extremes of length were $3-24 \mathrm{~cm}$. The average length of the appendix of male was $0.68 \mathrm{~cm}$ longer than that of the female ${ }^{2}$.

The length of the vermiform appendix is highly variable ranging from $2-20 \mathrm{~cm}$, average being $9 \mathrm{~cm}$. According to some authors it is more in children than in adults and may atrophy and becomes smaller after mid adult life ${ }^{8}$.

In a study of 101 autopsy appendices and over 3000 surgically resected appendices, the range of histopathological features seen in each groups described. Fibrosis and faecolith were more common in the older autopsy group than in the surgically resected group. The high incidence of fibrosis in the autopsy group suggests that this was an age related change, although some might be due to previous inflammation ${ }^{9}$.

J Bangladesh Soc Physiol. 2007 Dec;(2): 13-16.
The present study, observed that the range of length of vermiform appendix were from $2.6 \mathrm{~cm}$ (group D, sex female, post ileal) to $14 \mathrm{~cm}$ ( group $\mathrm{B}$, male sex, pelvic position).

The mean length was found $7.56 \mathrm{~cm}$ in male and $7.97 \mathrm{~cm}$ in female. So here the length of vermiform appendix of female was found to be slightly longer than those in male. Among all groups and sex, the length of vermiform appendix in group A was maximum.

Therefore, we can reasonably conclude that in middle age (35 years) and in advancing age the appendix gradually shortens due to atrophy with age.

In this study the length of vermiform appendix almost match with other workers. Here the range of the length $2.6 \mathrm{~cm}$ to $14 \mathrm{~cm}$ instead of $2 \mathrm{~cm}$ to $20 \mathrm{~cm}$. Mean length in this study was found 7.56 $\mathrm{cm}$ in male and $7.9 \mathrm{~cm}$ in female whereas other researchers found it to be $9 \mathrm{~cm}$.

\section{Conclusion}

If the length and position of vermiform appendix can detected by sonographally will help to decrease the complication of appendicular pathology by its early and easy diagnosis. Perforation of long pre ileal position appendix causes diffuse peritonitis, short post ileal positioned appendicitis leads 'Missed appendicitis. Long pelvic \& subcaecal positioned appendicitis causes irritation of urinary bladder. Short retrocaecal positioned appendicitis masked sign symptoms of appendicitis. Long retro colic positioned appendicitis may cause right flank pain and incomplete decent of caecum with its long retrocolic positioned appendicitis make confuse with cholecystitis. As its base is fixed but by its length increase the area of differential diagnosis of surgical abdomen. 


\section{Author Affiliations}

1. Dr Md Mahbubur Rahman, MBBS, M Phil; Curator, Department of Anatomy, Mymensingh Medical College, Bangladesh

2. Professor Dr Mohsin Khalil, MBBS, M Phil, Professor and Head of Anatomy, Mymensingh Medical College, Bangladesh

3. Professor Dr Mansur Khalil, MBBS, M Phil, Ph D, DFM; Deputed to Centre for Medical Education, Mohakhali, Dhaka, Bangladesh

4. Professor Dr Anwar Hussain, Professor and Head of the Department of Forensic Medicine, Mymensingh Medical College, Bangladesh

5. Dr Habibur Rahman Rahman, MBBS, M Phil; Assistant Professor, Department of Anatomy, Mymensingh Medical College, Bangladesh

6. Dr Sabina Mannan, MBBS, M Phil; Assistant Professor, Department of Anatomy, Mymensingh Medical College, Bangladesh

7. Dr Seheli Zannat Sultana, Assistant Professor, Department of Anatomy, Mymensingh Medical College.

8. Dr M Shibbir Ahamed, MBBS, M Phil, Lecturer of Anatomy, Mymensingh Medical College, Bangladesh

\section{References}

1. Moore KL, Persaud TVN editors. $7^{\text {th }}$ ed. The developing human. London: Saunders; 2003. P. $256-60$.
2. Schwartz SI, Principles of surgery, $7^{\text {th }}$ ed, McGrawHill, International edition health profession Division: 1998, p. $1383-93$.

3. Ross MH, Koye GI, Pawlina W, editors. Histology: A text and atlas, $5^{\text {th }}$ ed. Baltimore: Willims and Wilkins; 2005. P. 528-574.

4. Snell RS. Clinical Anatomy. $7^{\text {th }}$ ed. Baltimore: Lippincott William and Wilkins; 2004. P. 215 - 7.

5. Borley NR. Editor, Microstructure of the large intestine. In: Berkovitz KBB, Borley NR, Crossman AR, Davis MS, Fitzgerald MJT, Glass J, et. al editors. Grays anatomy: the anatomical basis of clinical practice. $39^{\text {th }}$ ed, Edinburgh: Elsevier Churchill Livingstone; 2005, P. 1173 - 86.

6. Ajmani ML, Ajmani K. The position, length and arterial supply of vermiform appendix. Anat Anz. 1983; 153(4): 369 - 74

7. Das S. A concise Text book of surgery. $1^{\text {st }}$ ed. Calcutta; S.D. Publishers; 1996, P.966.

8. O'connel PR. The vermiform appendix. In: Russel RCG, Norman SW, Christopher JKB; editors Bailey's and Loves short practice of surgery. $24^{\text {th }}$ ed. London: International student ed; 2004, P.1203 - 18.

9. Lally KP, Cox CS, Andrasy RJ editor. Appendix. In: Townsend, Beauchmp, Everts, Mattox Sabiston Text book of Surgery, vol. II. $7^{\text {th }}$ ed. Saunders; 2004. P. 1381 -99 . 